XVI. The lepidopterous genus Cocytia. By AвтнUR G. Butler, F.L.S., F.Z.S., \&c.

[Read May 7th, 1884.]

The genus Cocytia was founded by Dr. Boisduval in 1829 : he says of it (Mon. Zyg., p.4), "Je l'ai établi sur un très-bel insecte rapporté de la Nouvelle-Guinée par M. le capitaine Durville"; and he refers it to the Zygenida.

In 1874 Dr. Boisduval published his " Monographie des Agaristidées " in the 'Revue et Magasin de Zoologie,' pp. 26-110, and he there erected a tribe Cocytides for the reception of the single species Cocytia durvillei.

In February, 1875, I published "Notes on certain genera of Agaristide, with descriptions of new species," in the 'Annals and Magazine of Natural History,' pp. 135-144; in this paper I raised the species to the rank of a family Cocytiide, to be placed between the Agaristide and Zygenide, and at the same time I added the description of a second species from the Aru Islands, C. chlorosoma.

The family Cocytiida is characterised by its long erect palpi, unusually developed in the female so as to resemble the palpi, in some species, of the Noctuid genus Ophideres; in its antennæ it more nearly resembles the Castniida than either the Agaristida or Zygenida, but even more closely some genera of Hesperiida; these organs are long, straight, gradually clubbed towards the distal extremity, and then tapering and curved at the tip; the body is as robust as in the most powerful Bombyces, and the form, transparency and coloration of the wings, reminds one vividly of the Sphingid genus Hemaris; the neuration, however, though in some respects like that of Hemaris, yet shows certain features characteristic of the transparent-winged Zyganida.

The one genus yet known has, so far, consisted of TRANS. ENT. SOC. LOND. 1884.-PART III. (оСT.) 
two species, to which I now have to add a third (lent to me for description by my friend Walter de Rothschild); it was obtained by Mr. Veitch's collector, Charles Curtis, at Batchian, and, at $\mathrm{Mr}$. Rothschild's request, I name it C. veitchii.

The characters of the three species of Cocytia can be best indicated by a key thus :-

a. Wings hyaline-white, with broad black borders and thickened black internervular streaks gradually tapering from the external border; reddish orange subbasal patch on primaries large $\quad . \quad$..

$b$. Wings hyaline-white, with narrow black external borders; internervular streaks narrower and emitted abruptly from the external border ; reddish orange subbasal patch small and rounded ...

C. durvillei.

c. Wings hyaline-yellowish, with narrow black external borders; internervular streaks emitted abruptly ; reddish orange subbasal patch large

C. chlorosoma.

C. veitchii.

The following are the species:-

\section{Cocytia durvillei.}

Cocytia durvillei, Boisduval, Mon. Zyg., p. 22, pl. i., fig. 1 (1829) ; Sp. Gén. Lep., i., pl. 15, fig. 1 (1858).

Male and female, New Guinea; male, Port Moresby ; female, Ké Dulan; B. M.

2. Cocytia chlorosoma.

Cocytia chlorosoma, Butler, Ann. \& Mag. Nat. Hist., ser. 4, vol. 15, p. 144 (1875).

Male, Aru, B. M.

We only possess two male examples of this species.

\section{Cocytia veitchii, n. s.}

As large as $C$. durvillei, but the wings of a transparent yellowish colour (not due to scales, as these are absent from the clear portions of the wing-surface), the black external borders narrow as in C. chlorosoma, the rays or intermediate streaks being emitted abruptly as in that species, so that the inner edge of the external border is not sinuated as in $C$. durvillei; primaries with the orange subbasal patch as large as in the latter species, and of a similar 
form; centre of the abdomen of a more golden metallic-green than in either the New Guinea or the Aru species. Expanse of wings, $89 \mathrm{~mm}$.

Batchian (C. Curtis). Coll. W. Rothschild.

It will be seen, from the foregoing description, that this species, though differing from $C$. durvillei and $C$. chlorosoma in its yellower wings, is in other respects intermediate in character. 


\section{$2 \mathrm{BHL}$ Biodiversity Heritage Library}

1884. "XVI. The lepidopterous genus Cocytia By Abthur G. Butler, F.L.S., F.Z.S." Transactions of the Entomological Society of London 32, 351-353. https://doi.org/10.1111/j.1365-2311.1884.tb01611.x.

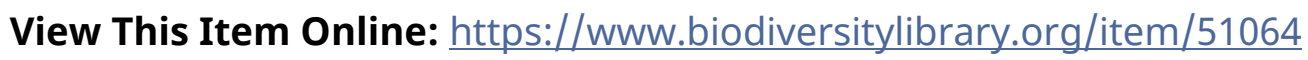

DOI: https://doi.org/10.1111/j.1365-2311.1884.tb01611.x

Permalink: https://www.biodiversitylibrary.org/partpdf/25219

\section{Holding Institution}

Smithsonian Libraries

\section{Sponsored by}

Smithsonian

\section{Copyright \& Reuse}

Copyright Status: Public domain. The BHL considers that this work is no longer under copyright protection.

This document was created from content at the Biodiversity Heritage Library, the world's largest open access digital library for biodiversity literature and archives. Visit BHL at https://www.biodiversitylibrary.org. 